\title{
Metode Analisis Diskriminan dalam Pengelompokan Kabupaten/Kota di Provinsi Sulawesi Selatan Berdasarkan Indikator Indeks Pembangunan Manusia
}

\author{
Novi Afryanthi S.*, Muhammad Arif Tiro, \& Ansari Saleh Ahmar \\ Program Studi Statistika, Fakultas Matematika dan Ilmu Pengetahuan Alam, Universitas Negeri Makassar, Indonesia
}

Keywords: Cluster analysis, Discriminant analysis, Human development index indicator.

\begin{abstract}
:
Discriminant analysis is a method in multivariat statistic analysis that related with object which have separated into the defined group defined and see the accuracy of the formed group. In this research, clustera analysis is used for the first grouping, cluster analysis is a statistical analysis which aims to classify some objects based on the characteristics similarity among the object. Data for this study is HDI (Human Development Index) of indicator in south sulawesi in 2016. The result of this research are 1st cluster (lower HDI indicator) which have 21 city/ distric and the 2nd cluster (higher HDI indicator) which have 3 city/distric as the closeness value between the cluster that formed is 0.902 which shows the closeness between the cluster is high . Furthermore, the discriminant function that have formed explains that if the life expectancy increase, the HDI indicator in city/distric in south sulawesi province will decrease but if school expectation duration in school, average of duration in school, and parity of pur hasing power is increasing, the HDI indicator in city/distric in aouth sulawesi will also increase.
\end{abstract}

\section{Pendahuluan}

Analisis Diskriminan merupakan teknik statistika untuk mengelompokkan individu-individu ke dalam kelompokkelompok yang saling bebas dengan tegas berdasarkan segugus peubah bebas (Matjik, 2004). Analisis diskriminan adalah teknik statistika multivariat yang terkait dengan pemisahan atau alokasi/klasifikasi (classification) sekelompok objek ke dalam kelompok yang telah terlebih dahulu didefinisikan. Dalam tujuan pengenalan objek (observasi), metode ini mencoba menemukan suatu 'diskriminan' yang nilainya secara numeris sedemikian sehingga mampu memisahkan objek yang karakteristiknya telah diketahui. Sedangkan dalam tujuan klasifikasi objek, metode ini akan mensortir objek (observasi) kedalam 2 atau lebih kelas (Amir Hamzahan; Gatot Santosa; dan Wisnu Widiarto, 2002). Pengelompokan pada analisis diskriminan bersifat mutually exclusive, yaitu jika suatu objek telah dimasukkan dalam satu kelompok maka tidak dapat menjadi anggota kelompok lain. Setelah pengelompokan, analisis diskriminan juga berguna dalam melihat keakuratan pengelompokan yang terbentuk. Dalam penelitian ini, penulis akan menggunakan Analisis Diskriminan dalam Pengelompokan Kabupaten/Kota di Provinsi Sulawesi Selatan Berdasarkan Indikator IPM pada tahun 2016. Indeks Pembangunan Manusia (IPM) merupakan pendekatan untuk mengukur pencapaian pembangunan yang ditekankan pada kesejahteraan masyarakat.

Tinggi rendahnya IPM kabupaten/kota di Provinsi Sulawesi Selatan hanya ditunjukkan oleh Indeks Komposit, tetapi tidak ditunjukkan indikator mana yang dominan terhadap tinggi/rendahnya peringkat IPM. Padahal nilai dari tiap-tiap

\footnotetext{
* Corresponding author.

E-mail address: noviafryanthi@gmail.com
} 
indikator pembentuk IPM perlu dilihat agar dapat diketahui pencapaian dari tiap-tiap indikator. Pengelompokan wilayah kabupaten/kota di Provinsi Sulawesi Selatan perlu dilakukan sebagai bahan perencanaan dan evaluasi sasaran program pemerintah untuk meningkatkan angka pembangunan manusia. Sehingga, untuk mengetahui pengelompokan dengan keakuratan yang tepat pada kabupaten/kota berdasarkan indikator IPM dapat digunakan analisis diskriminan.

\section{Tinjauan Pustaka}

\subsection{Analisis Diskriminan}

Analisis diskriminan adalah salah satu teknik statistika yang bisa digunakan pada hubungan dependensi (hubungan antarpeubah dimana sudah bisa dibedakan mana peubah respon dan mana peubah penjelas).

\section{Asumsi Diskriminan}

1. Multivariate normality, yang dalam hal ini berarti peubah independen seharusnya berdistribusi normal. Jika data tidak berdistribusi normal, hal ini akan menyebabkan masalah pada ketepatan fungsi (model) diskrimanan. Regresi logistik (logistic regression) bisa dijadikan alternatif metode jika memang data peubah independen tidak berdistribusi normal secara nyata.

2. Matriks kovarians dari semua peubah indepeden seharusnya sama (equal).

3. Tidak ada korelasi antarpeubah independen. Jika dua peubah independen mempunyai korelasi yang kuat, maka dikatakan terjadi multikolinieritas. Seperti pada analisis regresi berganda, terjadinya multikolinieritas akan menyebabkan biasanya interpretasi dari model yang terbentuk.

4. Tidak adanya data sangat ekstrim (outler) pada peubah independen. Jika ada data outler dan proses pengolahan tetap dilakukan hal ini bisa berakibat berkurangnya ketepatan klasifikasi dari fungsi diskriminan.

Analisis Diskriminan Linear atau Linear Discriminant Analysis (LDA) dapat digunakan sebagai metode klasifikasi maupun reduksi dimensi pada sebuah set data. Tujuan utama dari analisis diskriminan adalah untuk memperoleh kaidah matematis, yang dikenal dengan fungsi diksriminan, yang dapat digunakan untuk memisahkan kelompok objek yang berbeda. Misalkan pada data terdapat $p$ peubah bebas dan $j$ kelompok, dengan $n_{i}$ adalah jumlah pengamatan untuk pengamatan ke-i. Suatu pengamatan baru akan ditempatkan pada salah satu kelompok berdasarkan fungsi diskriminan berikut:

$$
D_{i}=b_{0}+b_{1} x_{1 j}+b_{2} x_{2 i}+b_{p} x_{p i}
$$

dengan:

$D_{i} \quad=$ skor diskriminan untuk pengamatan ke- $i$

$x_{p i} \quad=$ nilai pengamatan ke- $i$ peubah ke- $p$

$b_{p} \quad=$ koefisien diskriminan peubah ke- $p$

\subsection{Pengelompokkaan Awal}

Analisis cluster merupakan suatu teknik analisis multivariat yang mempunyai tujuan untuk mengelompokkan data peubah atau observasi ke dalam cluster sedemikian rupa sehingga masing-masing cluster bersifat homogen sesuai dengan faktor yang digunakan untuk melakukan clustering. Karena yang diinginkan adalah untuk mendapatkan cluster yang sehomogen mungkin, maka yang digunakan sebagai dasar untuk clustering adalah kesamaan skor nilai yang dianalisis. Data mengenai ukuran kesamaan tersebut dapat dianalisis dengan analisis cluster sehingga dapat ditentukan siapa yang masuk cluster mana (Gudono, 2011 dalam Sofya Laeli, (2014))

\section{Metode Penelitian}

Jenis data yang digunakan dalam penelitian ini adalah data sekunder yang dipublikasikan oleh Badan Pusat Statistika (BPS) Provinsi Sulawesi Selatan yaitu data indikator indeks pembangunan manusia (IPM) Tahun 2016. Tahap awal dari analisis pengelompokan adalah merumuskan masalah dengan mendefinisikan peubah-peubah yang dipergunakan untuk dasar klasifikasi. 
Teknik Analisis Data:

1) Tahap awal dari analisis pengelompokan adalah merumuskan masalah dengan mendefinisikan peubah-peubah yang dipergunakan untuk dasar klasifikasi.

2) Sampel yang diambil harus benar-benar bisa mewakili populasi.

3) Melakukan eksplorasi data.

4) Standarisasi data dan pengecekan asumsi.

Standarisasi data jika terdapat perbedaan nilai yang besar antar peubah yang dapat menyebabkan bias dalam analisis pengelompokan maka data asli perlu standarisasi. Misalnya, ada yang dalam satuan juta dan ada yang satuan puluhan atau bahkan lebih kecil. Perbedaan data yang besar akan menyebabkan perhitungan jarak menjadi tidak valid.

5) Melakukan penentuan kelompok awal menggunakan analisis cluster.

6) Pengujian asumsi analisis diskriminan.

7) Melakukan uji signifikan dari fungsi diskriminan.

8) Melakukan uji keeratan hubungan fungsi diskriminan.

9) Membentuk fungsi diskriminan.

10) Kesimpulan.

\section{Hasil dan Pembahasan}

\subsection{Standarisasi Data}

Sebelum melakukan pengolahan data dengan metode cluster dan diskriminan, terlebih dahulu dilakukan standarisasi peubah. Standarisasi digunakan ketika terdapat perbedaan satuan yang berbeda. Pada penelitian ini, data yang digunakan memiliki satuan yang berbeda maka dilakukan standarisasi data. Hasil standarisasi data Indikator dan IPM. Berdasarkan tabel dibawah, telah dilakukan standarisasi sehingga satuan dari setiap peubah telah sama. Selanjutnya, dapat dilanjutkan dengan melakukan pengelompokan peubah menggunakan cluster hirarki. Pada metode cluster, hal awal yang perlu dilakukan yaitu penetuan ukuran kemiripan antar objek.

\subsection{Proses Analisis Diskriminan}

\subsubsection{Pengujian Asumsi Diskriminan}

a. Uji Normal Multivariat

Tabel 1 Uji Normal Multivariat

\begin{tabular}{ccc}
\hline & Nilai Statistikaa & $p$-value \\
\hline Kurtosis & 4,464 & 0,903 \\
Skewness & 4,623 & 0,328 \\
\hline
\end{tabular}

Berdasarkan tabel 1, didapatkan nilai signifikansi dari kurtosis dan skewness, nilainya lebih besar dari 0,05 $(p-$ value $>\alpha=0,05$ ), artinya data berdistribusi normal multivariat.

b. Uji Kesamaan Matriks Kovarians

Tabel 2 Uji Kesamaan Matriks Kovarians

\begin{tabular}{cccc}
\hline & K-Squared & $d f$ & $p$-value \\
\cline { 2 - 4 } Barlett Test & 0.453 & 1 & 0,500 \\
\hline
\end{tabular}

Berdasarkan tabel 2, terlihat bahwa pada uji kesamaan matriks kovarians menggunakan uji barlett test, diperoleh nilai p-value $=0,500(>\alpha=0,05)$, sehingga dapat disimpulkan bahwa matriks kovarians akan relatif sama untuk kedua kelompok. 
c. Uji Multikolonieritas

Tabel 3 Uji Multikolonieritas

\begin{tabular}{ccc}
\hline Peubah & Tolerance & VIF \\
\hline $\mathrm{X}_{1}(\mathrm{AHH})$ & 0,478 & 2,094 \\
$\mathrm{X}_{2}(\mathrm{HLS})$ & 0,167 & 6,002 \\
$\mathrm{X}_{3}(\mathrm{RLS})$ & 0,123 & 8,133 \\
$\mathrm{X}_{4}$ (PDB) & 0,482 & 2,076 \\
\hline
\end{tabular}

Berdasarkan tabel 3, terlihat bahwa nilai toleransi setiap peubah lebih besar dari 0,10. Sementara itu, untuk nilai VIF dari setiap peubah lebih kecil dari 10,00. Sehingga dapat disimpulkan bahwa peubah-peubah tersebut tidak mengalami multikolonieritas.

\subsubsection{Pembentukan Fungsi Diskriminan}

Terdapat empat peubah yang terseleksi masuk dalam analisis, yaitu angka harapan hidup, harapan lama sekolah, ratarata lama sekolah, dan paritas daya beli. Sebelum melanjutkan ke analisis diskriminan, terlebih dahulu akan dimunculkan rata-rata nilai peubah dari masing-masing kelompok yang terbentuk.

Tabel 4 Rata-Rata Nilai Peubah Dari Tiap Kelompok

\begin{tabular}{ccccc}
\hline Kelompok Indikator IPM & AHH & HLS & RLS & PDB \\
\hline Rendah & 68,383 & 12,755 & 7,187 & 9630,619 \\
\hline Tinggi & 70,793 & 14,760 & 10,450 & 13711,667 \\
\hline
\end{tabular}

Berdasarkan tabel 4, terlihat bahwa terdapat perbedaan rata-rata dari setiap peubah pada masing-masing kelompok. Nilai rata-rata setiap peubah untuk kelompok Indikator IPM rendah, rata-ratanya lebih kecil dibanding nilai rata-rata setiap peubah untuk kelompok Indikator IPM tinggi.

a. Uji Signifikan Diskriminan

Tabel 5 Uji Signifikan Diskriminan

\begin{tabular}{ccccc}
\hline Test of Function & Wilk's $\boldsymbol{\lambda}$ & Chi-square & df & p-value \\
\hline 1 & 0,176 & 34,687 & 4 & 0,001 \\
\hline
\end{tabular}

Berdasarkan tabel 5, dapat dilihat bahwa nilai signifikan 0,001 ( $p$-value $<\alpha=0,05)$, maka $\mathrm{H}_{0}$ ditolak sehingga disimpulkan bahwa peubah-peubah yang diteliti memiliki perbedaan antar kelompok.

b. Uji keeratan Hubungan Diskriminan

Tabel 6 Uji Keeratan Hubungan

\begin{tabular}{ccccc}
\hline Function & Eigenvalue & \% $\boldsymbol{p} \boldsymbol{f}$ Variance & Cumulative \% & Canonical Correlation \\
\hline 1 & 4,365 & 100 & 100 & 0,902 \\
\hline
\end{tabular}

Berdasarkan tabel 6, Canonical Correlation mengukur keeratan hubungan antara diskriminant score dan group (dalam hal ini, karena ada dua cluster yang terbentuk, maka ada dua group). Angka 0,902 menunjukkan keeratan yang tinggi, dengan ukuran skala asosiasi antara 0 sampai 1

c. Fungsi Diskriminan

Berdasarkan tabel 7, fungsi diskriminan pada prinsipnya membuat semacam persamaan regresi, dengan pembagian berdasarkan kode cluster. Adapun fungsi diskriminan yang terbentuk yaitu:

$$
D=-0,2307 A H H+0,1454 H L S+1,7725 R L S+0,0001 P D B
$$


Berdasarkan fungsi diskriminan tersebut, dapat dijelaskan jika penambahan angka pada peubah Angka Harapan Hidup, maka nilai indikator IPM di kabupaten/kota di Provinsi Sulawesi Selatan akan menurun. Tetapi jika penambahan angka pada peubah Harapan Lama Sekolah, Rata-rata Lama Sekolah, dan Paritas Daya Beli, maka nilai indikator IPM di kabupaten/kota di Provinsi Sulawesi Selatan akan meningkat.

Tabel 7 Nilai Parameter

\begin{tabular}{cc}
\hline Peubah & Parameter \\
\hline $\mathrm{X}_{1}(\mathrm{AHH})$ & $-0,2307$ \\
$\mathrm{X}_{2}(\mathrm{HLS})$ & 0,1454 \\
$\mathrm{X}_{3}(\mathrm{RLS})$ & 1,7725 \\
$\mathrm{X}_{4}(\mathrm{PDB})$ & 0,0001 \\
\hline
\end{tabular}

\section{Kesimpulan}

1. Berdasarkan analisis pengelompokan awal, pengelompokan 24 kabupaten/kota di Provinsi Sulawesi Selatan berdasarkan indikator IPM menggunakan metode cluster hirarki, dapat dibentuk 2 cluster, dengan cluster 1 (kelompok Indikator IPM rendah) beranggotakan 21 kabupaten/kota yaitu Selayar, Bulukumba, Bantaeng, Jeneponto, Takalar, Gowa, Sinjai, Maros, Pangkep, Barru, Bone, Soppeng, Wajo, Sidrap, Pinrang, Enrekang, Luwu, Tana Toraja, Luwu Utara, Luwu Timur, dan Toraja Utara. Sedangkan cluster 2 beranggotakan 3 kabupaten/kota yaitu Makassar, Pare-pare, dan Palopo.

2. Ukuran keeratan hubungan antara 2 cluster yang terbentuk berada pada angka 0,902 yang menunjukkan keeratan yang tinggi, dengan ukuran skala asosiasi antara 0 sampai 1.

3. Berdasarkan analisis diskriminan, diperoleh fungsi diskriminan sebagai berikut:

$$
D=-0,2307 A H H+0,1454 H L S+1,7725 R L S+0,0001 P D B
$$

Sehingga dapat disimpulkan jika penambahan angka pada peubah Angka Harapan Hidup, maka nilai indikator IPM di kabupaten/kota di Provinsi Sulawesi Selatan akan menurun. Tetapi jika penambahan angka pada peubah Harapan Lama Sekolah, Rata-rata Lama Sekolah, dan Paritas Daya Beli, maka nilai indikator IPM di kabupaten/kota di Provinsi Sulawesi Selatan akan meningkat. Atau kita juga bisa menyimpulkan sebagai berikut, semakin tinggi nilai Angka Harapan Hidup maka semakin rendah nilai indikator IPM dan semakin tinggi nilai Harapan Lama Sekolah, Rata-rata Lama Sekolah, dan Paritas Daya Beli maka nilai indikator IPM akan meningkat

\section{References}

Abubakar, Warda. (2007). Aplikasi Aanalisis Diskriminan pada Pengeluaran Daerah Di Provinsi Sulawesi Selatan. Makassar. Skripsi Fmipa UNM.

Annas, S., \& Irwan. (2015). Penerapan Analisis Diskriminan Dalam Pengelompokan Desa Miskin di Kabupaten Wajo. Indonesian Journal of Fundamental Sciences, $1(1)$.

Anuraga, G. (2015). Hierarchical Clustering Multiscale Bootstrap untuk Pengelompokan Kemiskinan di Jawa Timur. Jurnal Statistika Universitas Muhammadiyah Semarang, 3(1).

BPS. (2017). Indeks Pembangunan Manusia (IPM) Tahun 2016. Badan Pusat Statistika Provinsi Sulawesi Selatan.

Hamzahan, A., Santosa, G., \& Widiarto, W. (2002). Klasifikasi Objek Dalam Visi Komputer Dengan Analisis Diskriminan. Makara Journal of Technology, 6(1), 146732.

Laeli, S. (2014) . Analisis Cluster dengan Average Linkage Method dan Ward's Method untuk Data Responden Nasabah Asuransi Jiwa Unit Link . Skripsi.

Mattjik, A. A., dkk. (2004). Modul Teori Pelatihan Analisis Multivariat. Bandung: Departement Statistika. FMIPA IPB.

Santoso, S. (2017). Statistik Multivariat. Jakarta: PT. Elaks Media Komputindo.

Simamora, Bilson. (2005). Analisis Multivariat Pemasaran. Jakarta: PT. Gramedia Pustaka Utama. 
Siswadi,. \& Budi, S. (1989). Analisis Eksplorasi Data Peubah Ganda. Bandung: Jurusan Matematika. FMIPA IPB. Soraya, Y. (2011). Perbandingan Kinerja Metode Single LinkageMetode Complete Linkage, dan Metode K-Means dalam Analisis Cluster. Skripsi.

Tiro, M, A., Sukarna \& Aswi. (2010). Statistika Deskriptif Peubah Banyak. Makassar: Andira Publisher. 